Asia Proceedings of Social Sciences

(APSS)

www.readersinsight.net/APSS

THE ROLE OF INDUSTRY 4.0 TECHNOLOGIES IN DETERMINING THE TRIPLE BOTTOM LINE SUSTAINABILITY-A FRAMEWORK FOR MALAYSIAN SMES

\title{
Sreenivasan Jayashree
}

Associate Professor, Faculty of Management

Multimedia University,Persiaran Multimedia, 63100 Cyberjaya, Selangor

Malaysia

jayashree@mmu.edu.my

\section{Chinasamy Agamudainambi Malarvizhi}

Senior Lecturer, Faculty of Management

Multimedia University, Persiaran Multimedia, 63100 Cyberjaya, Selangor

Malaysia

malarvizhi@mmu.edu.my

\section{Mohammad Nurul Hassan Reza *}

Research Scholar, Faculty of Management

Multimedia University, Persiaran Multimedia, 63100 Cyberjaya, Selangor

Malaysia

hassanreza7171@gmail.com

*Corrosponding author's Email: hassanreza7171@gmail.com

Peer-review under responsibility of 4th Asia International Multidisciplinary Conference 2020 Scientific Committee

http://connectingasia.org/scientific-committee/

() 2020 Published by Readers Insight Publisher,

Office \# 6, First Floor, A \& K Plaza, Near D Watson, F-10 Markaz, Islamabad. Pakistan,

editor@readersinsight.net

This is an open access article under the CC BY-NC-ND license (http://creativecommons.org/licenses/by-nc-nd/4.0/). 


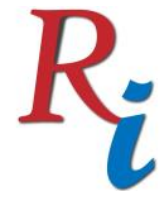

Asia Proceedings of Social Sciences

(APSS)

www.readersinsight.net/APSS

\section{A b s tra c t}

This study contributes to the current literature by analyzing the role of Industry 4.0 technologies on its effective implementation towards achieving Triple Bottom Line (TBL) sustainability. Several hypotheses are presented to evaluate the relationship, considering the role of Industry 4.0 technologies that may be played to determine TBL sustainability and effective implementation of Industry 4.0 as a mediating variable. Because there has been little focus on financial, ecological and societal sustainability and the role of Industry 4.0 technology on these dimensions in the current literature, this study aims to analyze the connection among the variables in relation to Malaysian SMEs. The statistical analysis will be performed through the employment of the Structural Equation Modeling (SEM).

\section{Rese a r ch H i g h I igh t s}

The rapid-growing global population, the need for a better life, and the continuing misuse of natural resources have grown a massive consciousness about sustainability to live, organize, performance, and manage tasks (Köhler et al., 2019). The term 'sustainability' has come to refer to 'maintain the business running'- an idiomatic definition by Colbert \& Kurucz (2007). Sustainability can be defined as a business strategy that involves long-term and long-lasting value creation and improves economic, ecological, and societal resources. This concept is close to Purvis et al. (2019), who define that sustainability involves concurrent attention on financial, ecological, and societal dealings. Similar to the expansion of Industry 4.0, sustainability has boomed through the combination of economic and environmental concerns into organizations' decision-making procedures (Gunasekaran \& Irani, 2014). SMEs are essential contributors to the world economies' springboard (Nor-Aishah et al., 2020). In Industry 4.0, organizations can achieve a platform for industry-based information systems that are flexible, transparent, smart, and up-to-date. By introducing Industry 4.0 organizations, can quickly access and evaluate the necessary technologies to address their demands. These technologies help organizations evolve with industrial manufacturing; they help fulfill the buyers' expectations and requests, raise the volume of production, supply chain, recycling, and involve all relevant facilities.

Internet of Things (IoT) is a modern architecture of manufacturing integrating intelligent and independent computers, innovative project assessments, and machine-human associations to enhance efficiency, skill, and productivity (Wong \& Kim, 2017). The IoT can be used in various fields to create sustainability (Bonilla et al., 2018), including improving resource efficiency and strengthening sustainable energy (Beier et al., 2018). IoT includes enormous possibilities for the end of life procedures (Song et al., 2015) or smart maintenance services (Chukwuekwe et al., 2016), and the overproduction can be reduced through the digital accessibility of buyer information (Beier et al., 2018). IoT technology can help organizations build sustainable practices by reducing energy consumption, introducing energy-efficient production systems, and sharing renewable energy (Beier et al., 2018). 


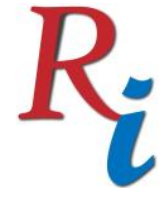

\section{Asia Proceedings of Social Sciences (APSS) \\ www.readersinsight.net/APSS}

In order to drive technological transformation, big data analytics are essential for organizations to analyze data or information. Consequently, they have a wide variety of expertise to build and understand the algorithms (Lee et al., 2017). Big Data tools can help develop natural resources consumption and management, enhance energy and ecological productivity, and achieve sustainability (Song et al., 2017). Scholars revealed that the big data can assist organizations in natural resources utilization and management, including energy consumption (Lin \& Lin, 2017), resources efficiency (Li et al., 2017), economic expansion, and resource protection (Xiao et al., 2016), fossil energy consumption (Wang \& Ye, 2017). On the other hand, researchers demonstrated, big data analytics can help organizations to achieve sustainability through the leveraging natural resources, such as water (Sun et al., 2017) and land (Li et al., 2017); construction (Zhang et al., 2017), transport (Li et al., 2017) and logistic sector (Wu et al., 2017), products improvement (Hazen, 2017), and business management (Tseng, 2017). Additionally, big data analytics can contribute to pollution prevention and treatment (Chen et al., 2017) and improving environmental efficiency (Chen \& Jia, 2017).

Cloud computing enables the networking of production materials, services, information, and humans over the internet in the manufacturing platform, building a smart and connected world. It helps organizations to enjoy the real potential of intelligent productivity in the manufacturing industries (Yue et al., 2015). Cloud computing can be the solutions to improve energy performance, to handle data center infrastructure efficiently (hardware and software), to minimize the cost of operations (Radu, 2017), to mitigate greenhouse pollution (Cappiello et al., 2015), and to leverage renewable energy (Bateman \& Wood, 2009).

The product is manufactured by improving additive manufacturing's consecutive coverings, where combining product parts and elements is not required. This technology enables organizations to manufacture small groups of classified items (Stock \& Seilger, 2016). The benefits of additive manufacturing include reduced waste generation because of an additive procedure, the potential for lightweight goods to minimize material and energy use, the resulting decrease in shipping in the supply chain, and the capacity to produce spare parts ondemand and eliminate excess inventory (Ford \& Despeisse, 2016).

Modern robots are autonomous, agile, and cooperative and will interact with humans very closely soon (Pei et al., 2017). The robots can help organizations create sustainability by accessing new resources from under the seas or lakes, reusing resources with the deployment of spectroscopic methods, which are difficult for the human being. The organization can employ robots in reducing waste during industrial production, manufacturing processes to generate fewer polluting by-products, aiding the repair of products, assisting in food production, and so on (Bugmann et al., 2011).

The organization's attention only on revenue-earning without addressing the stakeholder concerns has become significantly undesirable from a sustainability perspective (McWilliams et al., 2016). Accordingly, scholars have demonstrated sustainability design from the 'Triple 


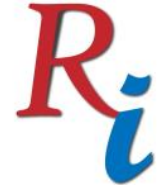

\section{Asia Proceedings of Social Sciences \\ (APSS) \\ www.readersinsight.net/APSS}

Bottom Line,' which includes profit, planet, and people, and this concept works from a financial, environmental, and social perspective (Norman et al., 2004).

\section{Research Objectives}

The primary intentions of this study are as follows,

- Examine the consequence of Industry 4.0 technology on its successful implementation.

- Assess the consequence of Industry 4.0 technology on TBL sustainability.

- Inspect the influence of Industry 4.0 on TBL sustainability.

- Scrutinize the mediating effect of Industry 4.0 between its technology and TBL sustainability.

\section{Research Framework}

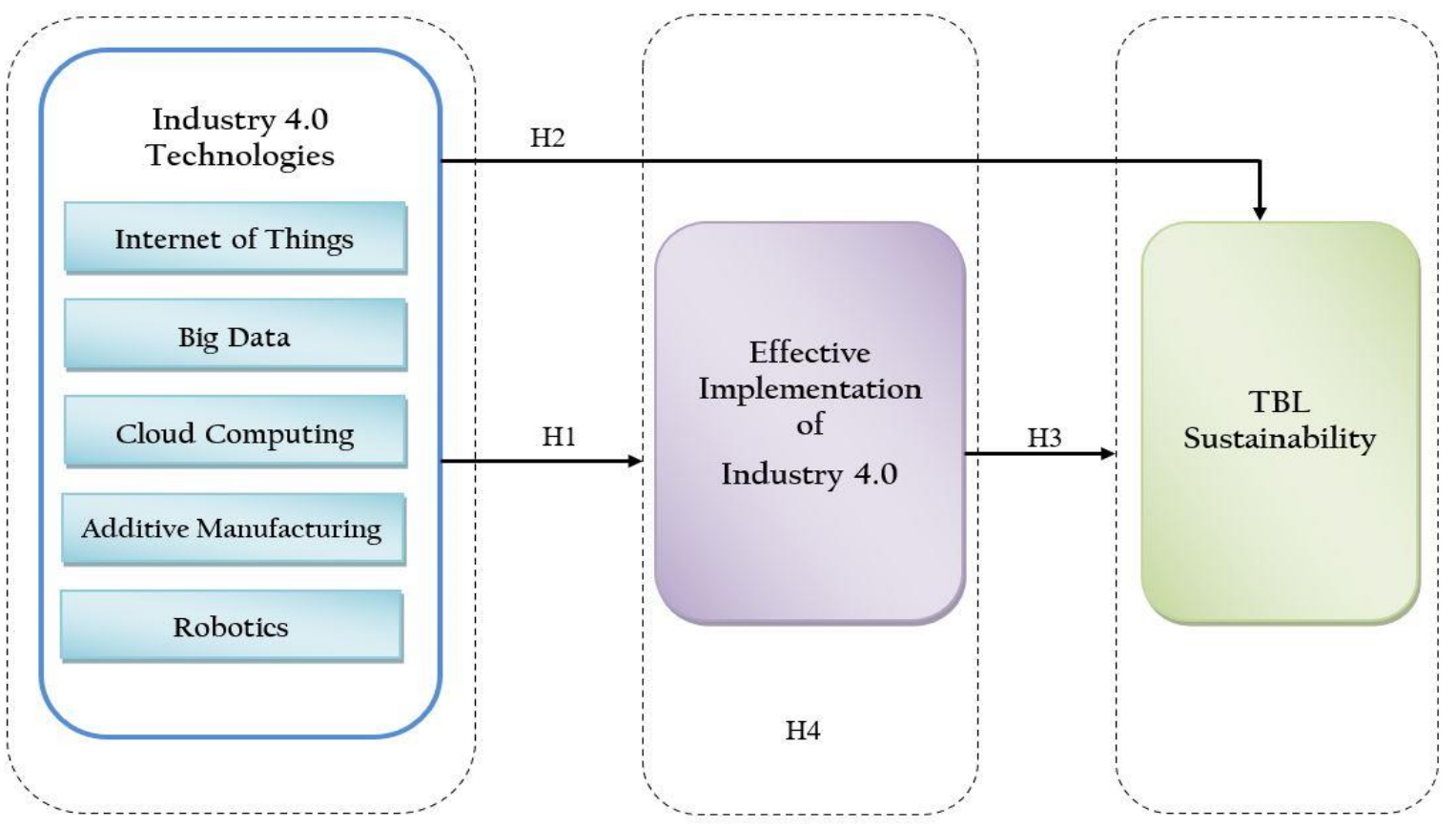

Fig. 1: Research Framework

\section{Methodology}

This study proposes a new model that includes Industry 4.0 technologies and the effect on Industry 4.0 accomplishment and sustainability in Malaysian SMEs. A cross-sectional survey will be carried out, and the samples will be collected from SME Corporation. The statistical analysis will be performed through the employment of the Structural Equation Modeling (SEM). 


\section{Findings}

This study focuses on the advancement of sustainable development through Industry 4.0 technologies in organizations. The study provided several hypotheses reflecting the linkages between the variables and. These hypotheses should be tested, and it would be essential to learn how Industry 4.0 technologies can help promote sustainability in the manufacturing sector.

\section{Acknowledgement}

The researchers are grateful to the Ministry of Higher Education, Malaysia for funding the study under the FRGS grant.

\section{References}

Bateman, A., \& Wood, M. (2009). Cloud computing. 25, 1475.

Beier, G., Niehoff, S., \& Xue, B. (2018). More sustainability in industry through industrial internet of things?. Applied sciences, 8(2), 219.

Bonilla, S. H., Silva, H. R., Terra da Silva, M., Franco Gonçalves, R., \& Sacomano, J. B. (2018). Industry 4.0 and sustainability implications: A scenario-based analysis of the impacts and challenges. Sustainability, 10(10), 3740.

Bugmann, G., Siegel, M., \& Burcin, R. (2011, September). A role for robotics in sustainable development?. In IEEE Africon'11 (pp. 1-4). IEEE.

Cappiello, C., Ho, N. T. T., Pernici, B., Plebani, P., \& Vitali, M. (2015). CO 2-Aware Adaptation Strategies for Cloud Applications. IEEE Transactions on Cloud Computing, 4(2), 152-165.

Chen, L., \& Jia, G. (2017). Environmental efficiency analysis of China's regional industry: a data envelopment analysis (DEA) based approach. Journal of Cleaner Production, $142,846-853$.

Chukwuekwe, D. O., Glesnes, T., \& Schjølberg, P. (2016). Condition Monitoring for Predictive Maintenance-Towards Systems Prognosis within the Industrial Internet of Things.

Colbert, B. and Kurucz, E. (2007). Three conceptions of triple bottom line business sustainability and the role for HRM, Human Resource Planning 30.

Ford, S., \& Despeisse, M. (2016). Additive manufacturing and sustainability: an exploratory study of the advantages and challenges. Journal of cleaner Production, 137, 15731587.

Gunasekaran, A., \& Irani, Z. (2014). Sustainable Operations Management: Design, Modeling and Analysis. Journal of the Operational Research Society, 65, 801-805. 


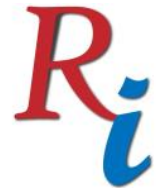

\section{Asia Proceedings of Social Sciences (APSS) \\ www.readersinsight.net/APSS}

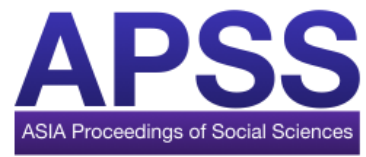

Hazen, B. T., Boone, C. A., Wang, Y., \& Khor, K. S. (2017). Perceived quality of remanufactured products: construct and measure development. Journal of Cleaner Production, 142, 716-726.

Köhler, J., Geels, F. W., Kern, F., Markard, J., Onsongo, E., Wieczorek, A., \& Fünfschilling, L. (2019). An agenda for sustainability transitions research: State of the art and future directions. Environmental Innovation and Societal Transitions, 31, 1-32.

Lee, Ju Yeon, Yoon, Joo Seong, Kim, Bo-Hyun, (2017). A big data analytics platform for smart factories in small and medium sized manufacturing enterprises: an empirical case study of a die casting factory. Int. J. Precis. Eng. Manuf. 18 (10).

Li, L., Hao, T., \& Chi, T. (2017). Evaluation on China's forestry resources efficiency based on big data. Journal of Cleaner Production, 142, 513-523.

Lin, B., \& Lin, J. (2017). Evaluating energy conservation in China's heating industry. Journal of Cleaner Production, 142, 501-512.

McWilliams, A., Parhankangas, A., Coupet, J., Welch, E., \& Barnum, D. T. (2016). Strategic decision making for the triple bottom line. Business Strategy and the Environment, 25(3), 193-204.

Nor-Aishah, H., Ahmad, N. H., \& Thurasamy, R. (2020). Entrepreneurial Leadership and Sustainable Performance of Manufacturing SMEs in Malaysia: The Contingent Role of Entrepreneurial Bricolage. Sustainability, 12(8), 3100.

Norman, W., \& MacDonald, C. (2004). Getting to the bottom of "triple bottom line". Business ethics quarterly, 14(2), 243-262.

Pei, Y. C., Chen, J. L., Wong, A. M., \& Tseng, K. C. (2017). An evaluation of the design and usability of a novel robotic bilateral arm rehabilitation device for patients with stroke. Frontiers in neurorobotics, 11, 36.

Purvis, B., Mao, Y., \& Robinson, D. (2019). Three pillars of sustainability: in search of conceptual origins. Sustainability science, 14(3), 681-695.

Radu, L. D. (2017). Green cloud computing: A literature survey. Symmetry, 9(12), 295.

Rubmann, M., Lorenz, M., Gerbert, P., Waldner, M., Justus, J., Engel, P., \& Harnisch, M. (2015). Industry 4.0: The future of productivity and growth in manufacturing industries. Boston Consulting Group, 9(1), 54-89.

SME Corp Malaysia. SME Annual Report 2017/2018; SME Corp Malaysia: Kuala Lumpur, Malaysia, 2018.

Song, M., Cen, L., Zheng, Z., Fisher, R., Liang, X., Wang, Y., \& Huisingh, D. (2017). How would big data support societal development and environmental sustainability? Insights and practices. Journal of Cleaner Production, 142, 489-500. 


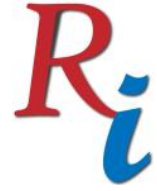

\section{Asia Proceedings of Social Sciences (APSS) \\ www.readersinsight.net/APSS}

Stock, T., Seliger, G., 2016. Opportunities of sustainable manufacturing in Industry4.0. Procedia CIRP 40, 536-541.

Sun, Y., Liu, N., Shang, J., \& Zhang, J. (2017). Sustainable utilization of water resources in China: A system dynamics model. Journal of cleaner production, 142, 613-625.

Tseng, M. L. (2017). Using social media and qualitative and quantitative information scales to benchmark corporate sustainability. Journal of Cleaner Production, 142, 727-738.

Wang, Z. X., \& Ye, D. J. (2017). Forecasting Chinese carbon emissions from fossil energy consumption using non-linear grey multivariable models. Journal of Cleaner Production, 142, 600-612.

Wong, K.S., Kim, M.H., 2017. Privacy protection for data-driven smart manufacturing system. Int. J. Web Serv. Res. 14 (3), http://dx.doi.org/10.4018/IJWSR.2017070102.

Wu, K. J., Liao, C. J., Tseng, M. L., Lim, M. K., Hu, J., \& Tan, K. (2017). Toward sustainability: using big data to explore the decisive attributes of supply chain risks and uncertainties. Journal of Cleaner Production, 142, 663-676.

Xiao, Y., Wu, X. Z., Wang, L., \& Liang, J. (2017). Optimal farmland conversion in China under double restraints of economic growth and resource protection. Journal of Cleaner Production, 142, 524-537.

Yue, X., Cai, H., Yan, H., Zou, C., Zhou, K. (2015). Cloud-assisted industrial cyber-physical systems: an insight. Microprocess. Microsyst. 39 (8), 1262-1270.

Zhang, Y., Ren, S., Liu, Y., \& Si, S. (2017). A big data analytics architecture for cleaner manufacturing and maintenance processes of complex products. Journal of Cleaner Production, 142, 626-641.

Author's Biography

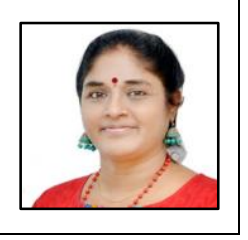

Dr Sreenivasan Jayashree, Associate Professor, Multimedia University, Cyberjaya, Malaysia has widely published in many international journals and has secured many grants. She has supervised many students. Her areas of interest are Environmental Management, Strategic Management, Industry 4.0, Waste Management, Consumer Studies. 


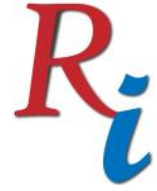

\section{Asia Proceedings of Social Sciences} (APSS)

www.readersinsight.net/APSS

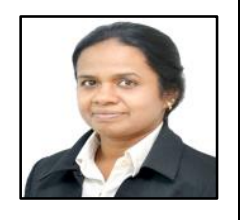

Dr Chinasamy Agamudainambi Malarvizhi, Senior Lecturer, Multimedia University, Cyberjaya, Malaysia has more than 18 years of teaching and research experience in Economics, Environment and Health issues, Knowledge Management and Tourism Development. She regularly publishes in journals and presents at international conferences. She has guided many PhD research scholars, Master students, and undergraduate students.

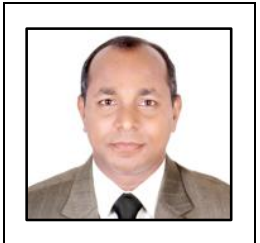

Mohammad Nurul Hassan Reza, Research Scholar, Faculty of Management, Multimedia University, Cyberjaya, Malaysia. Graduate Research Assistant of the project titled 'Testing a Framework for Industry 4.0 Digital Disruption-A Crunch Point for Environmental Sustainability in Malaysian SMEs', Ministry of Higher Education (MOHE), Malaysia. His areas of Interest are Fourth Industrial Revolution, Industrial Management, environmental management. 